\title{
Legalitas Tanah Wakaf Di Kota Bengkulu
}

\author{
Legality of Waqf Land in Bengkulu City \\ Miti Yarmunida, Nurul Hak, Loka Oktara \\ Fakultas Ekonomi dan Bisnis Islam \\ UIN Fatmawati Sokarno Bengkulu \\ miti_yarmunida@iainbengkulu.ac.id,nurul_hak@iainbengkulu.ac.id, \\ lokaoktara@gmail.com
}

Manuscript received 25 Oktober 2021, processed 26 Oktober 2021, published 31 Desember 2021

\begin{abstract}
Waqf land in Pematang Village, Governor of Muara Bangkabulu District, Bengkulu City 92\% do not have a certificate as a form of legality of waqf land. Based on the Waqf Law No. 41 of 2004 and PP No. 42 of 2006 that waqf assets must be recorded and certified. The purpose of this study is to describe the legality process of waqf land in Pematang Village, Governor of Muara Bangkabulu District, Bengkulu City and the obstacles faced in carrying out the legality of waqf land. The research method that the author uses is descriptive with a qualitative approach, primary data sources come from direct interviews with Nazir, secondary data sources come from articles, books, laws, online news that are relevant to the legality of waqf land. Data collection techniques with interviews, documentation studies. The data analysis technique was carried out since performing data reduction, displaying data and drawing research conclusions. The results of the research that the legality of waqf land in Pematang Village, Governor of Muara Bangkabulu District, Bengkulu City is in accordance with established regulations. The obstacle faced by Nazir in carrying out the legality of waqf land in Pematang Village, the Governor of Muara Bangkabulu District, was because the wakif's certificate of ownership of the waqf land was incomplete, and there was no record of the process of waqf land waqf.
\end{abstract}

Keywords: Legality, Waqf.

Abstrak: Tanah wakaf di Kelurahan Pematang Gubernur Kecamatan Muara Bangkahulu Kota Bengkulu 92\% tidak mempunyai sertfikat sebagai bentuk legalitas tanah wakaf. Berdasarkan Undang-Undang Wakaf Nomor 41 Tahun 2004 dan PP Nomor 42 Tahun 2006 bahwa harta wakaf wajib dilakukan pencatatan dan diterbitkan sertifikasinya. Tujuan penelitian ini adalah untuk menguraikan proses ligalitas tanah wakaf di Kelurahan Pematang Gubernur Kecamatan Muara Bangkahulu Kota Bengkulu dan kendala yang dihadapi dalam melakukan legalitas tanah wakaf. Metode penelitian yang penulis gunakan adalah deskriftif dengan pendekatan kualitatif, sumber data primer berasal dari hasil wawancara langsung kepada Nazir, sumber data sekunder berasal dari artikel, buku, undang-undang, berita online yang relevan dengan legalitas tanah wakaf. Tehnik pengumpulan data dengan wawancara, studi dokumentasi. Teknik analisa data dilakukan sejak melakukan reduksi data, display data dan menarik kesimpulan penelitian. Hasil penelitian bahwa proses legalitas tanah wakaf di Kelurahan Pematang Gubernur Kecamatan Muara Bangkahulu Kota Bengkulu sesuai dengan peraturan yang telah ditetapkan. Kendala yang dihadapi oleh nazir dalam melakukan legalitas tanah wakaf di Kelurahan Pematang Gubernur Kecamatan Muara Bangkahulu adalah karena surat menyurat hak milik wakif terhadap tanah wakaf tidak lengkap, dan tidak ada catatan proses mewakafkan tanah wakaf. 
Kata Kunci: Legalitas, Wakaf.

\section{PENDAHULUAN}

Masih banyak tanah wakaf yang ada di daerah-daerah di Indonesia belum tersertifkasi karena beberapa alasan. Padahal amanat Undang-Undang Nomor 41 Tahun 2004 telah jelas bahwa kegiatan mewakafkan tanah harus dicatat dan dibuatkan sertifikasinya sebagai upaya melindungi eksistensi tanah wakaf. Adapun tanah wakaf yang telah diwakafkan sebelum adanya regulasi tentang kewajiban pencatatan dan pensertifikasian tanah wakaf dapat dilakukan isbat wakaf dengan persyaratan dan prosedur yang telah ditentukan.

Banyak tanah wakaf yang tidak diketahui asal usulnya lagi, sehingga nazir sulit mengurus sertifikat tanah tersebut. Wakif dan nazir masih menganggap bahwa pencatatan tanah wakaf tidak terlalu penting sehingga dokumen pendukung untuk membuat akta ikrar wakaf dan sertifikasi tanah wakaf sulit dilakukan.

Tidak ada perintah yang jelas tentang kewajiban atau anjuran untuk membuat akkta ikrar wakaf dan sertifikat dalam Al-Quran maupun hadis, hal inilah yang menjadikan beberapa ulama menganggap bahwa mewakafkan harta tidak perlu didokumentasikan atau disertifikatkan. Ulama kontemporer memandang perlu dilakukan sertifikat terhadap harta wakaf untuk kemaslahatan dari harta wakaf itu sendiri.

Harta wakaf berupa tanah yang diatasnya dibangun masjid di Kelurahan Pematang Gubernur Kecamatan Muara Bangkahulu Kota Bengkulu ada 12 tanah wakaf. Tanah wakaf tersebut ada yang diwakafkan oleh pemiliknya sebelum keluar Undang-Undang Nomor 41 Tahun 2004 yang mewajibkan sertifikasi harta wakaf.

Walaupun hukum telah menata sedemikian lengkap ketentuan perwakafan di
Indonesia, tetapi kenyataan yang terjalin di masyarakat bahwa belum seluruh tanah wakaf berjalan teratur serta berdaya guna, alhasil terdapat banyak permasalahan harta wakaf tidak terpelihara dan seringkali kurang bermanfaat untuk kemaslahatan umat.

Tanah wakaf yang ada di Kecamatan Muara Bangkahulu mayoritas belum bersertifikat, khususnya di Kelurahan Pematang Gubernur. Tanah wakaf di Kelurahan Pematang Gubernur ada 12 lokasi yang diatasnya dibangun Masjid, dari 12 tanah wakaf tersebut cuma satu yang telah bersertifikat dan sebelas tanah wakaf belum bersertifikat, perihal itu tidak bisa dikira ringan sebab ini ialah mandat dari hukum kalau harta wakaf wajib dicatatkan.

Proses kegiatan mewakafkan harta wakaf harus dicatat serta dituangkan dalam Akta Ikrar Wakaf ( berikutnya disingkat AIW) serta didaftarkan pada lembaga terpaut buat didapat akta dan diumumkan yang penerapannya dicoba cocok dengan aturan metode yang diatur bagi peraturan perundangundangan yang mengatur tentang wakaf, ini bermaksud buat menghasilkan keteraturan hukum serta administrasi wakaf untuk mencegah permasalahan dalam pengolahan dan keberlanjutan harta wakaf.

Registrasi tanah wakaf sangat penting bila ditinjau dari sudut maslahah, tanah yang tidak dicatatkan sangat memungkinkan terjadinya penyimpangan dalam pengelolaan atau digugat untuk dikembalikan menjadi hak ahli waris. Dewasa ini semakin banyak kasus penyalahgunaan tanah wakaf dan gugatan ahli waris untuk mendapatkan hak atas tanah wakaf, inilah dampak tidak terdapatnya buktibukti tercatat, oleh sebab itu pengadministrasian tanah wakaf ialah perihal yang amat berarti supaya permasalahanpermasalahan di atas bisa dihindari. 
Instruksi kepala negara no 1 tahun 1991 tentang Kompliasi Hukum Islam mewajibkan terdapatnya wakaf dengan cara tercatat, tidak cukup cuma dengan perkataan saja. Tujuannya merupakan buat mendapatkan fakta asli yang hendak dipergunakan buat didaftarkan serta buat kebutuhan menuntaskan bentrokan yang mungkin terjadi dikemudian hari.

\section{METODE PENELITIAN}

Tipe riset ini memakai tipe riset deskriptif. Riset deskriptif ini memakai pendekatan kualitatif. Pendekatan kualitatif dalam riset ini dimaksudkan supaya penulis bisa mengenali serta melukiskan dan menganalisa kasus yang didapat di lapangan ialah data yang diperoleh dari Kantor Urusan Agama tentang data tanah wakaf yang sudah bersertifkiat dan yang belum bersertifikat serta hal-hal yang berkaitan dengan pensertifikatan tanah wakaf dengan cara saklek serta mendetail dan berupaya buat mengatakan informasi serta menguraikan mengenai kasus dalam cara persertifikasian tanah wakaf di Kelurahan Pematang Gubernur Kecamatan Muara Bangkahulu Kota Bengkulu

Informan penelitian ini ada 14 orang terdiri dari 12 orang Nazir, Kepala KUA Muara Bangkahulu sebagai PPAIW dan Staf KUA Muara Bangkahulu yang mengurus pencatatan harta wakaf.

Sumber data primer penelitian ini adalah hasil wawancara dengan informan secara langsung dan observasi yang peneliti lakukan di lokasi tanah wakaf. Sedangkan sumber data sekunder peneliti ambil dari peraturan yang relevan dengan penelitian ini, buku-buku, artikel, berita yang relevan dengan penelitian ini.

Teknik pengumpulan data dilakukan dengan wawancara terbuka dengan informan dan teknik dokumentasi terhadap instrument yang dapat mendukung kelengkapan data yang dibutuhkan.

Teknik analisis data dilakukan dengan menggunakan konsep Miles dan Huberman yaitu dengan cara interaktif dan berlangsung secara simultan pada setiap tahapan peneltian sampai tuntas. Mulai dari reduksi data, display data hingga tahapan verifikasi (penarikan kesimpulan).

\section{HASIL PENELITIAN DAN PEMBAHASAN}

\section{Regulasi Wakaf}

Mayoritas ulama mendefiniskan wakaf adalah menahan harta yang dapat dimanfaatkan dengan tetap mempertahankan keutuhan harta tersebut, wakif tidak dapat melakukan tasaruf ataupun pengwasan pada harta yang diwakafkan, pengelolaan harta wakaf diberikan seutuhnya kepada yang menerima harta wakaf untuk tujuan kebajikan dalam rangka mendekatkan diri kepada Allah swt. Harta yang sudah diwakafkan lepas dari kepemilikan orang yang mewakafkan dan menjadi milik Allah swt, hasil dari harta wakaf disedekahkan sesuai dengan tujuan wakaf, jika wakif wafat maka harta wakaf tidak dapat diwariskan kepada ahli waris.(Ubaidillah \& Saufi, 2017)

Definisi wakaf dalam Undang-Undang Nomor 41 Tahun 2004 pasal 1 ayat 1 adalah perbuatan hokum wakif untuk memisahkan dan/atau menyerahkan sebagian hartanya untuk dimanfaatkan selamanya atau untuk jangka waktu tertentu sesuai dengan kepentingan guna keperluan ibadah dan/atau kesejahteraan umum menurut syariat. (Bimas, 2004)

Implementasi regulasi legalisasi tanah wakaf di beberapa daerah mengalami kendala diantaranya kuantitas dan kualitas sumber daya manusia, pemahaman masyarakat yang masih 
minim, yang terlibat dalam proses pengurusan sertifikasi harta wakaf.(Wahab, 2018)

$$
\text { Implementasi regulasi tentang }
$$

sertifikasi tanah wakaf belum efektif karena beberapa kendala seperti sumber daya manusia yang mengelola tanah wakaf masih sedikit dan belum proaktif dalam mengatasi kendala sertifikasi tanah wakaf, di sisi lain pemahaman masyarakat tentang prosedur dan persyaratan mewakafkan tanah juga belum memadai. Sumber dana yang masih minim juga menjadi kendala pengelolah dalam melakukan sertifikasi tanah wakaf(Wahab, 2018)(S.H, 2017). Lemahnya sertifikasi tanah wakaf juga karena ada pendapat yang mengatakan bahwa sertifikasi tanah wakaf itu tidak perlu karena wakaf termasuk dalam permasalahan ibadah(Marginingrum \& Riadi, 2021). Pensertifikasian tanah wakaf merupakan upaya mewujudkan kemaslahatan pada tanah wakaf dan masyarakat(Ubaidillah \& Saufi, 2017). Permasalahan tanah wakaf sering terjadi karena wakif tidak mengkomunikasikan terlebih dahulu kehendaknya mewakafkan hartanya dengan calon ahli waris (Supraptiningsih, 2012).

Berdasarkan hasil penelitian yang dilakukan melalui observasi dan wawancara langsung kepada para nazhir di Kelurahan Pematang Gubernur dan Kepala KUA di Kecamatan Muara Bangkahulu. Terkait dengan sertifikat tanah wakaf di Kelurahan Pematang Gubernur, berdasarkan data yang diperoleh dari Kantor Urusan Agama (KUA) pada tahun 2018 bahwasannya sebagian besar kebanyakan tanah wakaf yang diperuntukan untuk masjid yaitu ada 11 yang belum bersertifikat dan 1 sudah bersertifikat dan hanya beberapa tanah wakaf yang diperuntukan selain masjid yaitu satu tanah wakaf untuk pemakaman, satu untuk paud, 4 untuk masjid lagi yang belum terdata di KUA yang saya peroleh dari hasil observasi di Kelurahan Pematang Gubernur. (Erdawati, 2019)
Berdasarkan wawancara yang peneliti lakukan, menggambarkan bahwasannya tanah wakaf di Kelurahan Pematang Gubernur kebanyakan yang belum bersertifikat, hal ini diperoleh dari hasil wawancara yang diperoleh dari informan yaitu bahwa kebanyakan nazhir belum melengkapi administrasi tanah wakaf, padahal tanah wakaf sangat penting untuk dilakukan karena hal ini tidak boleh dianggap enteng karena ini merupakan amanat dari undang-undang bahwa harta wakaf harus dicatatkan, oleh sebab itu administrasi tanah wakaf harus dilengkapi.

Bapak Bani Suparman mengatakan Bahwa ia belum mengurus sertifikat tanah wakaf karena persyaratan yang harus dipenuhi masih banyak yang kurang salah satunya yaitu sertifikat tanahnya hilang hal ini disebabkan bahwa pak Bani bukan nazhir yang pertama yang diberi amanat dari si wakif dan nazhir yang lama sudah meninggal. Jadi sertifikat tanah dari si pewakif sudah hilang ditambah lagi keluarga dari wakif tanah tersebut tidak diketahui lagi keberadaannya sehingga tanah wakaf tersebut tidak bisa disertifikatkan (Suparman, 2019)

Berbeda dengan bapak Wiriyono, ia mengatakan bahwa sertifikat tanah wakaf belum bisa dilakukan karena tidak diketahui siapa pewakifnya, dan nazhir pengurus yang lama sudah pindah dan tidak diketahui tempatnya begitu pula dengan pewakifnya (Wiriyono, 2019)

Selanjutnya bapak M. Kauli mengatakan : "tanah wakaf ini belum bersertifikat karena terkendala dalam masalah biaya dan prosesnya yang cukup lama (Kauli, 2019)

Sama halnya yang diungkapkan oleh bapak Abdul Munir dan juga bapak H.a Hasani, bahwa yang menyebabkan tanah wakaf yang diperuntukan untuk masjid ini terkendala dalam masalah biaya sehingga mereka tidak 
mau mengurusnya lagi dan sampai sekarang juga tidak ada masalah atau gugatan dari masyarakat (Hasani, 2019).

Untuk tanah wakaf yang sudah bersertifikat, bapak Daman Aksah mengatakan bahwa tanah wakaf memang harus mempunyai sertifikat walaupun melalui proses yang lama karena berguna untuk menjaga dan melindungi harta wakaf. Tanah masjid Al-Muttaqin merupakan masjid pertama di kelurahan Pematang Gubernur dan sudah memenuhi persyaratan untuk disertifikatkan dan biaya yang digunakan dari kas masjid (Arsah, 2019)

Berikut data masjid, wakif, nazhir, dan sertifikat tanah wakaf yang menjadi objek penelitian.

\section{Tabel 1}

Data Masjid dan legalitas wakafnya

\begin{tabular}{|c|c|c|c|c|}
\hline No & $\begin{array}{l}\text { Nama } \\
\text { Masjid }\end{array}$ & Wakif & Nazhir & Sertifikat \\
\hline 1 & $\begin{array}{l}\text { AL- } \\
\text { Mukmin }\end{array}$ & Makri & $\begin{array}{l}\text { Daman } \\
\text { Aksah }\end{array}$ & Ada \\
\hline 2 & $\begin{array}{l}\text { Al- } \\
\text { Mukmin }\end{array}$ & $\begin{array}{l}\text { Juwairi } \\
\text { yah }\end{array}$ & $\begin{array}{l}\text { Bani } \\
\text { Suparman }\end{array}$ & Belum \\
\hline 3 & $\begin{array}{l}\text { Al- } \\
\text { Baroqah }\end{array}$ & $\begin{array}{l}\text { Ali } \\
\text { Tjasah }\end{array}$ & Jauhari M & Belum \\
\hline 4 & $\begin{array}{l}\text { Al- } \\
\text { Fathonah }\end{array}$ & $\begin{array}{l}\text { Rahma } \\
\mathrm{t} \\
\text { Sunant } \\
\mathrm{o}\end{array}$ & $\begin{array}{l}\text { Warga } \\
\text { Masyrakat }\end{array}$ & Belum \\
\hline 5 & $\begin{array}{l}\text { Darrusala } \\
\mathrm{m}\end{array}$ & - & Wiriyono & Belum \\
\hline 6 & Al-Ghafari & $\begin{array}{l}\mathrm{Hj} . \\
\text { Kartina }\end{array}$ & Mawaldin & Belum \\
\hline 7 & $\begin{array}{l}\text { Baiturrah } \\
\text { man }\end{array}$ & $\begin{array}{l}\text { Sanadu } \\
\text { us }\end{array}$ & Joni Batran & Belum \\
\hline 8 & $\begin{array}{l}\text { Al- } \\
\text { Muhtadin }\end{array}$ & - & Mustaqim & Belum \\
\hline 9 & $\begin{array}{l}\text { Al- } \\
\text { Muhajirin }\end{array}$ & $\begin{array}{l}\text { Darma } \\
\mathrm{n}\end{array}$ & $\begin{array}{l}\text { Khairil } \\
\text { Anwar }\end{array}$ & Belum \\
\hline 10 & Jihadul & $\begin{array}{l}\text { Mustaf } \\
\text { a dan } \\
\text { Ayun }\end{array}$ & Muslih Hs & Belum \\
\hline 11 & Al-Khair & $\begin{array}{l}\text { Lili } \\
\text { Suryani }\end{array}$ & M. Kauli & Belum \\
\hline 12 & Al-Ikhlas & $\begin{array}{l}\mathrm{Hj} . \\
\text { Lisa } \\
\text { Ulanda }\end{array}$ & Abdul Munir & Belum \\
\hline
\end{tabular}

\begin{tabular}{|l|l|l|l|l|}
\hline & & ri & & \\
\hline 13 & $\begin{array}{l}\text { Raudhatul } \\
\text { Jannah }\end{array}$ & $\begin{array}{l}\text { H. } \\
\text { Sofyan } \\
\text { Salim }\end{array}$ & H.a Hasani & Belum \\
\hline
\end{tabular}

Sumber data diperoleh dari KUA Kecamatan Muara Bangkahulu, 2017 Berdasarkan data tersebut, bahwa ada 11 masjid yang belum bersertifikat dan hanya 1 yang sudah bersertifikat. Untuk masjid Darrusalam itu juga belum bersertifikat dan belum terdata oleh KUA, hal itu diketahui setelah melakukan penelitian di Kelurahan Pematang Gubernur.

\section{Prosedur Legalisasi Tanah Wakaf}

Prosedur dan persyaratan sertifikasi tanah wakaf telah ditetapkan di dalam regulasi. Berdasarkan hasil wawancara dapat diketahui bahwa proses sertifikasi tanah wakaf di Kelurahan Pematang Gubernur Kecamatan Muara Bangkahulu Kota Bengkulu dilakukan sesuai dengan yang telah ditetapkan oleh Undang-Undang dan Peraturan lainnya. (Dimyati, 2019)

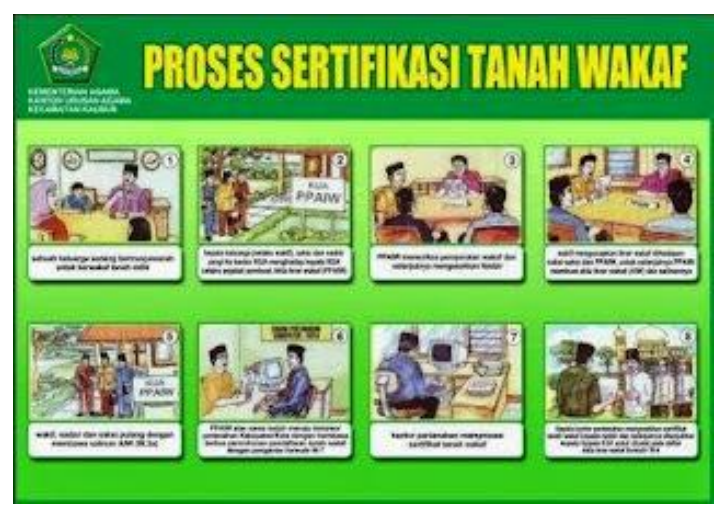

\section{Gambar 1: Proses Sertifikasi Tanah Wakaf}

Pengurusan sertifikat tanah wakaf untuk tanah milik yang sudah bersertifikat dilakukan dan syarat-syarat sebagai berikut :

a. Pewakif harus datang ke PPAIW dengan membawa: sertifikat hak atas tanah, surat keterangan Kepala Desa/Lurah yang diketahui Camat bahwa tanah tersebut tidak dalam sengketa, serta Surat Keterangan 
Pendaftaran Tanah (SKPT) dari Kantor Pertanahan Kabupaten/Kota setempat.

b. Pewakif mengikrarkan wakaf dengan lisan, jelas, dan tegas kepada nadzir di hadapan PPAIW dihadapan para saksi, kemudian dituangkan dalam bentuk tertulis11 menurut formulir W.1.

c. Apabila pwakif tidak datang di hadapan PPAIW maka harus memberikan kuasa tertulis secara matreatik di hadapan notaris dan/ dihadapan Kepala Kantor Departemen Agama Kabupaten/Kota dan dibacakan kepada nadzir dihadapan PPAIW dan para saksi.

d. PPAIW membuat Akta Ikrar Wakaf (AIW) rangkap 3 (tiga) menurut bentuk formulir W.2 dan salinannya rangkap 4 (empat) menurut bentuk formulir W.2.a.

e. PPAIW atas nama nadzir dan/ nadzir sendiri berkewajiban untuk mengajukan permohonan pendaftaran pada Kantor Pertanah Kabupaten/Kota setempat dengan menyerahkan: sertifikat tanah yang bersangkutan, Akta Ikrar Wakaf, dan surat pengesahan dari KUA kecamatan setempat mengenai nadzir yang bersangkutan.66

f. Kepala Kantor Pertanahan Kabupaten/Kota setempat:

Mencantumkan kata "wakaf" dengan huruf besar di belakang nomor hak milik tanah yang bersangkutan pada buku tanah dan sertifikatnya. (2) Mencantumkan kata-kata: "diwakafkan untuk.....berdasarkan Akta Ikrar Wakaf PPAIW kecamatan.....No.....pada halaman 3 (tiga) kolom sebab perubahan dalam buku tanah dan sertifikatnya. (3) Mencantumkan kata nadzir, nama nadzir disertai kedudukannya pada buku tanah sertifikatnya.

Prosedur sertifikasi tanah wakaf dari hak milik yang belum bersertifikat (bekas tanah hak milik adat) dilakukan dan dengan syarat sebagai berikut :

a. Persyaratan pembuatan Akta Ikrar Wakaf :

1. Surat-surat pemilikan tanah (termasuk surat pemindahan hak, surat keterangan warisan, girik, dan lain-lain).

2. Surat Kepala Desa/Lurah yang diketahui Camat yang membenarkan tanah tersebut tidak dalam sengketa.

3. Surat keterangan Kepala Kantor Pertanahan Kabupaten/Kota setempat yang menyatakan Hak Atas tanah itu belum mempunyai sertifikat.

b. Proses pembuatan Akta Ikrar Wakaf dan pendaftaran pencatatan Ikrar Wakaf sebagaimana proses untuk tanah yang sudah bersertifikat.

c. Apabila memenuhi syarat untuk dikonversi, maka dapat dikonversi langsung atas nama wakif.

d. Apabila persyaratan untuk dikonversi tidak dipenuhi dapat diproses melalui prosedur pengakuan hak atas nama wakif.

e. Berdasarkan Akta Ikrar Wakaf dibalik nama ke atas nama nadzir.

f. Bagi konversi yang dilaksanakan melalui prosedur pengakuan hak, penerbitan sertifikatnya setelah diperoleh SK. Pengakuan Hak atas nama wakif. Selanjutnya dilaksanakan pencatatan sebagaimana dikemukakan pada angka 1 huruf f. (Dimyati, 2019)

Tanah yang belum ada haknya dalam hal ini adalah tanah yang sudah berstatus tanah wakaf atau tanah yang sudah berfungsi sebagaimana tanah wakaf, sementara masyarakat dan Pemerintah Desa setempat setelah mengakui sebagaimana tanah wakaf, sedangkan status tanahnya adalah tanah yang belum ada haknya atau tanah negara, yaitu : 
1. Wakif atau ahli warisnya masih ada dan mempunyai surat bukti penguasaan/penggarapan

2. Surat keterangan Kepala Desa/Lurah yang diketahui Camat tentang penggunaan tanah yang diwakafkan.

3. Surat Keterangan Pendaftaran Tanah (SKPT) dari Kantor Pertanahan Kabupaten/Kota setempat yang menerangkan status tanah negara tersebut apabila sudah pernah terdaftar atau menerangkan belum bersertifikat apabila tanah negara itu belum terdaftar.

Calon Wakif atau ahli waris datang menghadap PPAIW untuk melaksanakan Akta Ikrar Wakaf. PPAIW atau nadzir berkewajiban mengajukan permohonan atas kepada Kakanwil Pertanahan Nasional Propinsi melalui Kepala Kantor Pertanahan Kabupaten/Kota setempat dengan menyerahkan surat-surat di atas. Kantor Pertanahan Kabupaten/Kota setempat memproses dan meneruskan permohonan kepada Kakanwil Badan Pertanahan Nasional Propinsi. Setelah diterbitkan Surat Keputusan Pemberian Hak Atas Tanah atas nama nadzir, kepala kantor pertanahan Kabupaten/Kota menerbitkan sertfikat wakaf (Dimyati, 2019).

Wakif atau ahli warisnya masih ada, tetapi tidak mempunyai surat bukti penguasaan terhadap tanah yang diwakafkan, maka prosedur dan persyaratan pengurusan sertifikat tanah wakaf tersebut sebagai berikut:

1. Surat Keterangan Kepala Desa/Lurah yang diketahui Camat tentang perwakafan tanah tersebut dan tidak dalam sengketa, serta kebenaran penguasaan/penggarapan oleh calon wakif.

2. Proses selanjutnya sebagaimana tersebut pada huruf a angka 2 sampai 6. c. Wakif atau ahli warisnya tidak ada. Surat keterangan tentang tanah (kalau ada).

3. Surat Kepala Desa/Lurah diketahui Camat tentang perwakafan.

4. Surat pernyataan tentang perwakafan tanah dari orang- orang yang bersebelahan dengan tanah tersebut.

5. Nadzir atau Kepala Desa/Lurahmendaftarkannya kepada KUA Kecamatan setempat.

6. Kepala KUA meneliti dan mengesahkan nadzir.

7. PPAIW membuat akta pengganti AIW.

8. PPAIW atas nama nadzir dan atau nadzir mengajukan permohonan Hak Atas Tanah.

9. Permohonan hak, SK Pemberian Hak Atas Tanah, dan penerbitan sertifikat.69

Prosedur yang sudah dilakukan oleh pihak KUA masih sangat terbatas yaitu hanya untuk tanah wakaf yang sudah lengkap syaratnya dari awal ketika proses wakaf dilakukan. Sementara tanah wakaf yang belum lengakp suratsuratnya belum diselesaikan pengurusan sertifikatnya karena berbagai kendala. (Dimyati, 2019)

\section{Kendala dalam mengurus sertifikat tanah wakaf yang ada di Kelurahan Pematang Gubernur}

Kendala-kendala yang menyebabkan tanah wakaf belum disertifikatkan disebabkan karena para nazhir belum melengkapi persyaratan untuk melakukan sertifikasi tanah wakaf ditambah lagi pihak dari KUA juga tidak pernah turun langsung ke lapangan untuk memantau bagaimana para nazhir melaksanakan tugasnya. Menurut bapak kepala KUA mereka hanya menyediakan pelayanan untuk proses persertifikasian. (Dimyati, 2019)

Tanah wakaf yang diatasnya didirikan bangunan mesjid yang bernama Al-Muhtadin 
ini terletak di Jalan Supraman kelurahan Pematang Gubernur mulai dibangun sekitar tahun 2011. Menurut penuturan Mustakim selaku pengelola masjid bahwa status tanah ini adalah tanah wakaf, namun mereka tidak mengetahui siapa yang mewakafkan tanah maupun nadzirnya sudah meninggal dan ahli warisnya tidak diketahui sampai sekarang, diketahui status tanah itu adalah tanah wakaf berdasarkan penuturan dari anak nadzir, namun ia juga tidak mengetahui siapa wakif tanah tersebut (Mustaqim, 2019)

Masalah yang dihadapi dalam mengelola mesjid ini surat- suratnya belum lengkap, surat-surat tanah wakaf segala macam atau SKTnya tidak ada, kesulitan ngurus sertifikatnya karena wakif dan nadzirnya sudah meninggal, ahli warisnya tidak diketahui keberadannya, jadi itu problemnya. sebenarnya kami ingin saja mengurus tanah wakaf ini karena kami ingin membuat yayasan, apalagi ini kan aset dan surat- surat itu penting, tapi ya mau bagaimana. kami bingung harus melakukan apa, kami tidak tahu bagaimana prosedurnya supaya tidak menyalahi dari ketentuan hukum Islam maupun legalitas undangundangnya (Mustaqim, 2019)

Nazir pernah lapor ke KUA, namun sampai saat ini belum ada jalan keluar, mereka mengatakan bahwa pengelola harus mengurus surat- suratnya biar jelas status tanahnya, ada program sertifikat gratis atau pemutihan atau apa lah itu, namun kami makin bingung, mereka tidak menjelaskan bagaimana mengurus sertifikat apabila wakif, nadzir sudah meninggal dan ahli warisnya tidak diketahui keberadaannya (Mustaqim, 2019)

Berdasarkan wawancara di atas, nadzir kesulitan mengurus tanah wakafnya, sama halnya juga dengan masjid Al-Fathonah di Jln. Penantian berdiri pada tahun 2011 yang dikelola oleh warga masyarakat itu sendiri dan masjid Baiturrahman di Jln. W.R Supratman yang berdiri sekitar tahun 1995 yang dikelola oleh Joni Batran. Mereka kesulitan mengurus tanah wakaf yang nadzir, wakif dan ahli warisnya tidak ada. Hingga sampai saat ini, tanah wakaf masjid ini tidak memiliki suratsurat yang jelas dan ukurannya pun tidak diketahui karena tidak memiliki SKT atau surat-surat keterangan yang lain.

Sedangkan masjid Al-Barokah berdiri sekitar tahun 2002 di jalan Wr. Supraman kelurahan Pematang Gubernur.

Menurut bapak Ali Tjasah, ia mengatakan bahwa untuk kelengkapan suratsuratnya belum ada lagi sampai sekarang, belum kami buat lagi, tidak masalah kan. Memang dulu ada suratnya, surat pelepasan tanah tapi itu surat sudah hilang alasannya tidak ada, karena memang selama ini tidak ada masalah sampai sekarang. Mungkin nanti kalau ada masalah atau gugatan baru nanti kami urus. Selama ini masyarakat juga tidak terlalu mempersoalkan hal tersebut, tapi nanti insya allah kedepannya kami pengelola dengan ahli waris wakif berencana akan mengurus suratsuratnya sampai saat ini belum ada lagi himbauan secara khusus dari KUA tentang kelengkapan surat-suratnya (Tjasah, 2019)

Bapak Muslih Hs selaku nazhir dari masjid Jihadul juga mengungkapkan alasan yang sama tentang kendala yang menyebabkan tanah wakaf tersebut belum bersertifikat.

Selanjutnya masjid Al-Ghafari di Jln. Perintis berdiri pada tahun 2006 yang dikelola oleh bapak Mawaldin mengatakan bahwa problem yang dihadapi dalam mengelola masjid ini adalah pengurusan sertifikat yang belum tuntas sampai saat ini. Bukannya kami tidak mau ngurus, tapi surat-suratnya kaya SKT maupun sertifikat tanahnya tidak ada, sampai sekarang tidak ada itu surat-surat asalnya. Mungkin waktu itu proses perwakafannya secara lisan. Kalau seandainya surat-suratnya lengkap, pasti kami urus itu masjid, tapi ya mau bagaimana tidak lengkap suratnya, ahli warisnya pun sudah meninggal, jadi kami bingungnya disitu. Begitupun yang diungkapkan bapak Khairil Anwar selaku 
nazhir di masjid Al-Muhajirin. Mereka belum mengurus sertifikat karena pada waktu itu proses perwakafannya secara lisan yang didasari atas dasar saling percaya (Anwar, 2019).

Berdasarkan wawancara di atas, memang ada kesengajaan dari pengelola untuk tidak mengadministrasikan harta benda wakafnya. Menurutnya, sampai sekarang ini tidak pernah terjadi persoalan apapun mengenai status tanah wakaf tersebut, masyarakat juga tidak mempersoalkannya sehingga mereka tidak berniat untuk mendaftarkan tanah wakaf masjid tersebut. Tanah wakaf di atas merupakan tanah wakaf yang tidak memiliki kekuatan hukum tetap. Berbagai macam alasan dikemukakan oleh kelima nadzir diatas, diantaranya mereka kebingunan karena surat-surat pada saat awal proses perwakafan tidak lengkap kemudian nadzir maupun wakifnya sudah meninggal ditambah lagi ahli waris tidak diketahui keberadaannya ataupun lagi nadzir yang secara sengaja memang tidak mendaftarkan tanah wakaf tersebut karena dirasa bahwa selama ini tidak pernah terjadi masalah apa-apa, serta terkendala dalam masalah biaya dan prosesnya yang cukup lama.

\section{KESIMPULAN}

Legalisasi tanah wakaf mengalami beberapa kendala yang ditemukan di hampir seluruh daerah di Indonesia. Pemerintah Kota Bengkulu perlu melakukan kebijakan yang kongkrit untuk mewujudkan 100\% tanah wakaf di Kota Bengkulu tersertifikasi. Peran Badan Wakaf Indonesia dalam menertibkan legalitas tanah wakaf sangat signifikan melalui pembinaan, pemberdayaan nazdir yang sudah ada. Kemudian BWI bekerjasama dengan KUA dan Pemkot melakukan gerakan bersama untuk memberikan kesadaran kepada masyarakat tentang legalisasi tanah wakaf.

\section{DAFTAR KEPUSTAKAAN}

Marginingrum, P., \& Riadi, A. (2021). Efektifitas Sertifikasi Tanah Wakaf di Indonesia: Analisis Komparatif Fikih dan Hukum Positif. Management of Zakat and Waqf Journal (MAZAWA), 2(2). https://doi.org/10.15642/mzw.2021.2.2. 136-152

S.H, Y. (2017). Pelaksanaan Sertifikasi Tanah Wakaf Di Kalimantan Timur. Yuriska : Jurnal Ilmiah Hukum, 4(2). https://doi.org/10.24903/yrs.v4i2.184

Supraptiningsih, U. (2012). Problematika Implementasi Sertifikasi Tanah Wakaf Pada Masyarakat. Jurnal Nuansa, 9(1).

Ubaidillah, U., \& Saufi, M. (2017). Sertifikasi Tanah Wakaf Dalam Mewujudkan Kepastian Hukum: Studi Kasus Di Kecamatan Klangenan. Mabkamah : Jurnal Kajian Hukum Islam, 2(1). https://doi.org/10.24235/mahkamah.v2i 1.1664

Wahab, A. J. (2018). IWahab, Abdul Jamil. "Implementasi Kebijakan Sertifikasi Tanah Wakaf Di Kabupaten Serang Provinsi Banten Tahun Anggaran 2017." Harmoni 16, No. 2 (2018).Mplementasi Kebijakan Sertifikasi Tanah Wakaf Di Kabupaten Serang Provinsi Banten Tahun Anggaran 2017. Harmoni, 16(2). https://doi.org/10.32488/harmoni.v16i2 .8 